\title{
APPROPRIATE APPLICATION OF SAWOB M-BANKING TECHNOLOGY TO DEVELOP WASTE BANK MANAGEMENT IN BAE VILLAGE
}

\author{
Farid Noor Romadlon ${ }^{1}$, Dianing Ratna Wijayani ${ }^{2}$, Wiwit Agus Triyanto ${ }^{3}$ \\ Muria Kudus University ${ }^{1,2}$, and 3 \\ farid.noor@umk.ac.id ${ }^{1}$, ratna.wijayani@umk.ac.id ${ }^{2}$,at.wiwit@umk.ac.id ${ }^{3}$
}

\section{KEYWORDS \\ Waste management, \\ Sawob M-Banking \\ Technology, \\ waste recycle}

\section{ARTICLE INFO}

Accepted: January, $26^{\text {th }} 2022$

Revised: February, $11^{\text {th }} 2022$

Approved: February, $12^{\text {th }} 2022$

\section{ABSTRACT}

Garbage is a consequence of human activities. Along with the increasing population and current economic growth, waste management in the community creates uncontrolable problems. Based on this, one of the Community Service Program teams at Universitas Muria Kudus established a partnership with the Tanjung Seto Youth Organization in Bae village to help manage waste in the area. The main and urgent problem from partners that needs to be resolved is the operational activities of the waste bank. These problems include the socialization of waste bank activities, technical transactions, and circulation of waste bank savings money so that it is more efficient, effective, and practical and more citizens participate. The objective of this program is to assist the operational activities of the waste bank by using an android-based application named SAWOB M-Banking to support the process and mechanism of the Waste Bank activities. The method used to implement the solution is mentoring and knowledge transfer. Identifying needs will be accomplished through data collection on waste bank schedules, the number of waste bank clients, waste categories and price values, and customer savings data. Furthermore, processing the obtained data then making the SAWOB M-Banking application. The SAWOB M-Banking application has been socialized to customers gradually and tested for 10 customers in waste bank activities. After being simulated, the SAWOB M-Banking application has been used for all waste bank customers in Bae village.

\section{INTRODUCTION}

Garbage is a consequence of human activities. Along with the increase in population and current economic growth, waste management in the community creates problems that are difficult to control, such as what happened in the TPA where several environmental problems emerged including leachate water pollution, bad smells and air pollution due to open dumping and open burning practices. Waste in terms of quality and quantity is strongly influenced by the activities and standard of living of the community. Factors that affect the amount of waste include: population, geographical factors, time factors, socio-economic and cultural factors, weather, community habits, technological advances, types of waste (Deasy, 2020). Garbage is one of the environmental problems that needs serious attention where the quantity is increasing, the types and composition are increasingly varied, besides that various disease-causing organisms can live either directly or indirectly (Iftitah \& Musta'in, 2018) 
Waste management that does not use environmentally friendly waste management methods and techniques will have a negative impact on health and affect environmental sustainability (Asngad \& Subiakto, 2020). Handling residential waste requires the active participation of individuals and community groups in addition to the role of the government as a facilitator. People's ignorance of waste will result in environmental quality degradation which will affect the quality of life of people in an area (zzaty, Cholimah, \& Astuti, 2016). The current waste problem is not only the responsibility of the government but must be the responsibility of all levels of society in Indonesia. Various community efforts in managing and processing waste have been pioneered by environmental experts, community leaders/institutions that care about the environment (Arifin et al., 2020). The problem of waste is a problem that has not been resolved properly, especially in various regions in Indonesia. The amount of waste continues to increase every year. Government and public awareness of waste must be explored so that it can be separated from the waste problem (Wardany, Sari, \& Mariana, 2020). Local governments as the authorities in waste management have a great responsibility in solving waste management problems in their respective regions, both in terms of waste management in their respective areas, both in terms of management strategies, management permits and waste volume problems ( $\underline{\text { Santifa }}$ et al., 2019).

Waste management using the $4 \mathrm{R}$ principle (reduce, reuse, recycle, replant) has become a trend that has been carried out by the community, but in practice replanting (replanting) is not the choice of the majority of people so that the principle becomes 3R (reduce, reuse, recycle) (Wartama \& Nandari, 2020). Seeing the problems that occurred in the community, many ideas emerged from community organizations to create a work program called a waste bank. People can collect garbage to be exchanged for money. One of the organizations that have implemented this activity is the Tanjung Seto Youth Organization. This Garbage Bank runs every Sunday to borrow the vacant land of one of the Bae villagers. Until now, there are 350 people who have participated, from the previous 276 residents. The collection of types of waste and income also increases from year to year. Broadly speaking, the governance of a waste bank is similar to that of a conventional bank, where customers save and earn money. However, if the thing that is saved in the bank is money, then in the waste bank, what is

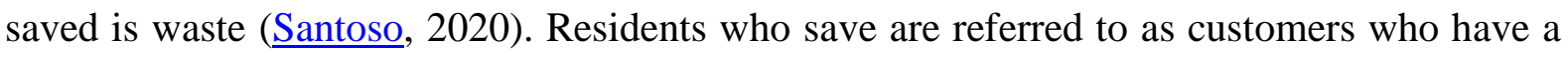
savings book and can borrow money which will later be returned with trash for the money borrowed. Waste bank is a strategy to build public awareness of waste to get direct economic benefits from waste (Luluk, 2018). The high level of public awareness in the waste problem and the existence of a waste bank are expected to be able to overcome the waste problem while creating a clean environment. The presence of a waste bank is a form of local wisdom that shows that the community already has awareness and concern for converting waste with more economic value (Dewanti et al., 2020). The economic advantage of this waste bank program is that it can increase family income even though it starts with small things, by sorting waste between organic and non-organic waste, this waste bank program is to overcome non-organic waste such as plastic waste, paper, iron (Muttaqien, Sugiarto, \& Sarifudin, 2019). The potential of the waste bank business can be developed into a business 
with high selling value, given the many benefits that can be obtained from waste that has been processed into handicrafts or fertilizer products (Nasution \& Ichsan, 2021).

Although this program has been running for the fourth year, there are still some difficulties faced by the waste bank management, including notification of activities that are still manual by borrowing public facilities for each activity; unavailability of land to temporarily accommodate waste before it is taken by collectors, causing some parts of the waste to be damaged by rain or eaten by rats or taken by people. Whereas good waste management will have a positive impact on the surrounding community, such as increasing public awareness and concern for environmental health and cleanliness (Khaira, Hasanah, \& Hayati, 2020).

The development of information technology is growing so fast it has the potential and opportunities to increase business productivity such as waste banks which have problems in terms of administrative data and the difficulty of accessing information by customers (Aziz \& Gumilang, 2018). Based on this, the community service program team formed a partnership with the Tunjung Seto Youth Organization in Bae Village, Bae District, Kudus Regency to assist waste management in the area by creating and implementing an Android-based system or application called SAWOB M-Banking for simplify the process of announcing waste bank activities, saving transactions for converting waste to cash value which will later become a balance in savings for residents or waste bank customers, notification of balance withdrawals, and other information such as updating waste exchange rates according to type and type of waste that can be recycled and has value. economical.

\section{METHOD RESEARCH}

This Community Service project was conducted at Tanjung Seto, Bae for three months, from November to January, intending to help Karang Taruna Tanjung Seto, Bae, and the surrounding community. The parties involved in this activity consist of a triple helix, including the Muria Kudus University team, Partners (Karang Taruna Tanjung Seto, Bae), and the Government (Housing Service, Settlement Areas, and the Environment). The method of implementing the activities carried out to partners is the method of mentoring and transfer of knowledge. The working procedures for implementing appropriate technology programs are the stages in the application of appropriate technology, namely:

The first is the identification of needs, namely collecting data related to waste bank activities such as schedules, types of waste, prices for types of waste, savings book data, or customer balances. The second is planning, which is processing the data for making applications. The third is implementation, namely making the SAWOB M-Banking application. The fourth is Simulation, namely socialization and testing of the SAWOB MBanking application. The fifth is implementation, namely assistance in the implementation of the SAWOB M-Banking application to waste bank administrators and customers. The sixth is Evaluation, namely monitoring the level of achievement of the application of the SAWOB M-Banking application.

Not only are the implementation stages needed in the realization of a program, but the ability of the team that is following the needs is very much needed. The Muria Kudus 
University team involved in this activity corresponds to the expertise required in the application of this program. The expertise needed is leadership, where one of the team members is the head of a department at Muria Kudus University. Furthermore, it takes an IT professional to supply knowledge (software programming); software and web development, as well as e-commerce system development and digital cooperative development in the village to construct a SAWOB M-Banking application. For recording and compiling financial reports that are useful for helping cooperatives in managing, analyzing, assessing financial reports, and evaluating budgets in waste bank management, experts in the field of financial accounting are needed. The three skills needed in implementing the program already cover all team members, team coordination, and scheduled implementation, the application of appropriate technology under the name SAWOB M-Banking can be carried out properly according to the plan and on time.

\section{RESULT AND DISCUSSION}

\section{Activity Implementation}

The output of Community Service activities at Karang Taruna Tunjung Seto is the application of technology in waste bank management to be more efficient, effective, and practically called SAWOB (Sampah Wong Bae) Mobile Banking. Information on waste delivery schedules; storage of waste conversion transactions to the value of money, which will later become a balance in residents' or waste bank customers' savings; balance withdrawal notification. Other information, such as updating the exchange rate of waste by type and types of waste that can be recycled and have economic value, as well as displays of necessities available at the cooperative are among the features of this application.

The steps are taken in the application of appropriate technology to develop waste bank management in Bae village, Bae sub-district, Kudus district are very concerned about the value of the needs of waste bank management. Before making the application, the team from the university identified the problem of the waste bank at Karang Taruna Tunjung Seto, Bae for 1 week. Based on the data collected, the team looked for solutions to these difficulties based on the needs in waste bank management. After identifying everything, the team started designing the system, design, and application of SAWOB M-Banking, the development of the Tunjung Seto cooperative, and the organization of vacant land for green open spaces, followed by construction, which took 4 weeks or 1 month. The finished application is not directly submitted to the Karang Taruna management, but a trial is carried out by the team internally. After confirming the design and deemed sufficient, the android-based application is ready to be disseminated to administrators and youth members so that they understand how to use it. The dissemination was carried out through training and mentoring for 6 meetings which were carried out online and offline.

At the first meeting, the training activity was attended by 27 participants which was carried out online via the zoom conference application at $19.30-21.00$. The training was continued on the second day with the same online media, namely zoom conference. The participants for mentoring activities on the second day were slightly reduced, namely around 20 participants. The strengthening of the exercise was carried out on day 3 with the number 
of participants increasing from the second day, namely 23 participants. After providing training, the team from Muria Kudus University assisted on the fourth day. In this first mentoring, it was done online using a zoom conference with a decrease in participants from the previous days, namely there were only 18 participants. During the four meetings, activities were carried out online and carried out at night starting from $19.30-21.00$. In the last two meetings, mentoring activities were carried out offline at the Bae Village Hall at 15.30 - 17.00 with 22 participants at the fifth meeting and 24 participants at the sixth meeting. The training and mentoring conducted by the Muria Kudus University Team were beneficial for the participants. By carrying out training and mentoring, Karang Taruna administrators and members can use the application following the features that have been presented.
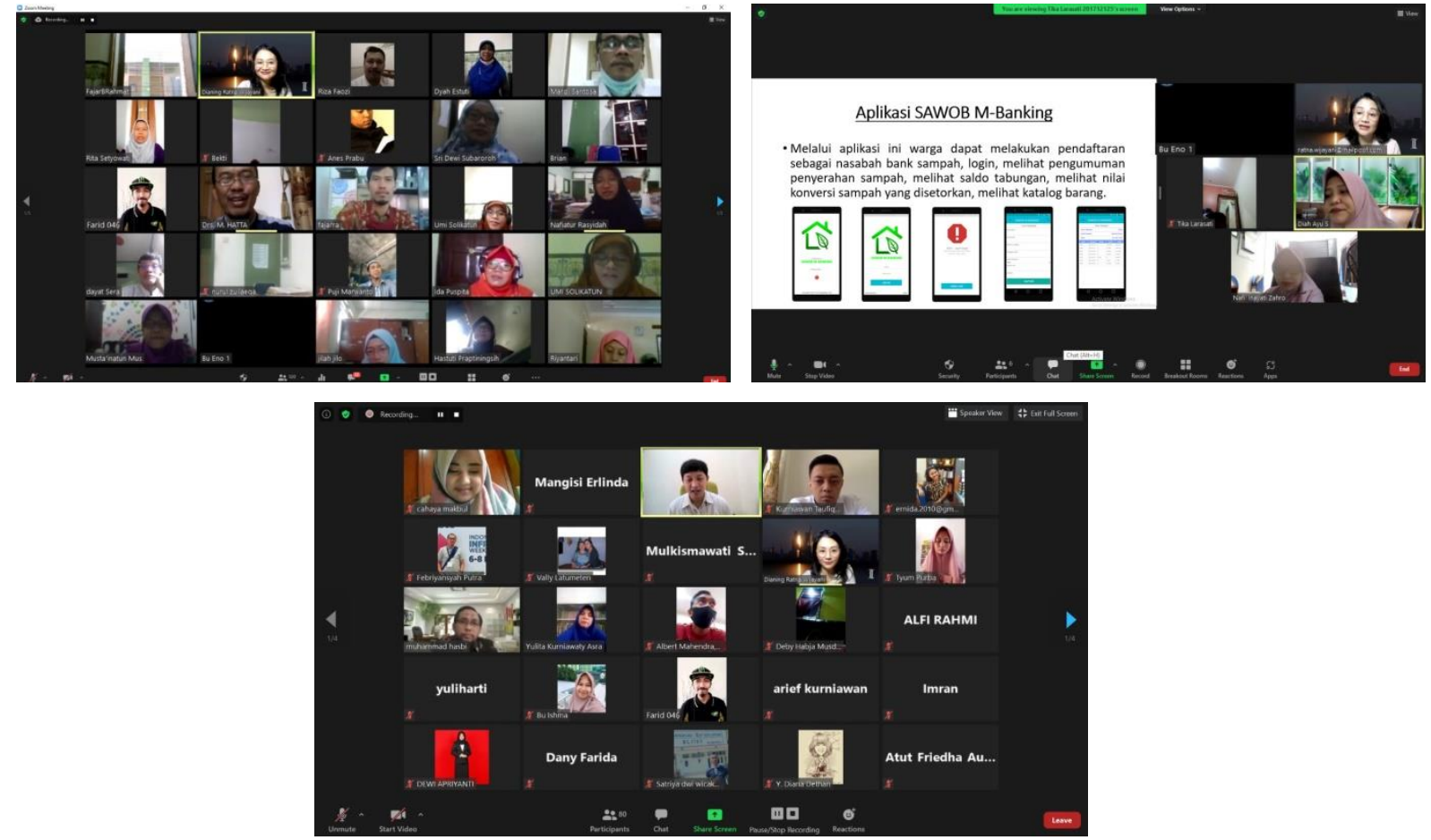

Figure. 1 Online Meetings

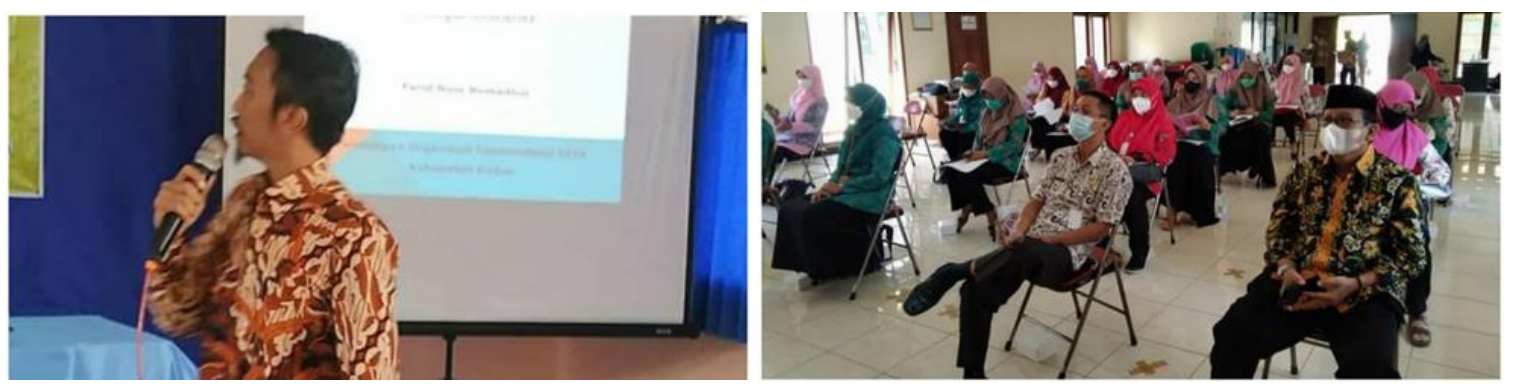

Figure 2. Offline meetings at Bae Village Hall 


\section{SAWOB Android Application Work Process (Sampah Wong Bae) Mobile Banking}

Residents can download the Android-based SAWOB M-Banking application from the Google Play Store. This android application was created using the Java programming language technology, firebase, MySQL database, and QR-Code. Through this application, residents can register as waste bank customers, log in, view announcements and waste delivery schedules, view savings balances, view the conversion value of deposited waste, view catalogs/displays of necessities available in cooperatives, and conduct cooperative shopping transactions. directly using a smartphone. Payment for items is made without the use of cash, but rather by scanning the QR-Code in the cooperative, and payment is successful if the savings account balance is sufficient.

How to use the features above is very easy, they just click on one of the features later will be choices. When going to choose the options provided, customers just click on one of these options.

In addition to the Android-based SAWOB M-Banking application specifically for customers, the manager of the waste bank cooperative also has a web admin application that can be accessed via a web browser. This web admin is used to manage customer data, information/announcements, waste conversion values, customer savings, cooperative catalogs, and QR-Code creation. The infrastructure design of the SAWOB M-Banking Application system can be seen in the picture.

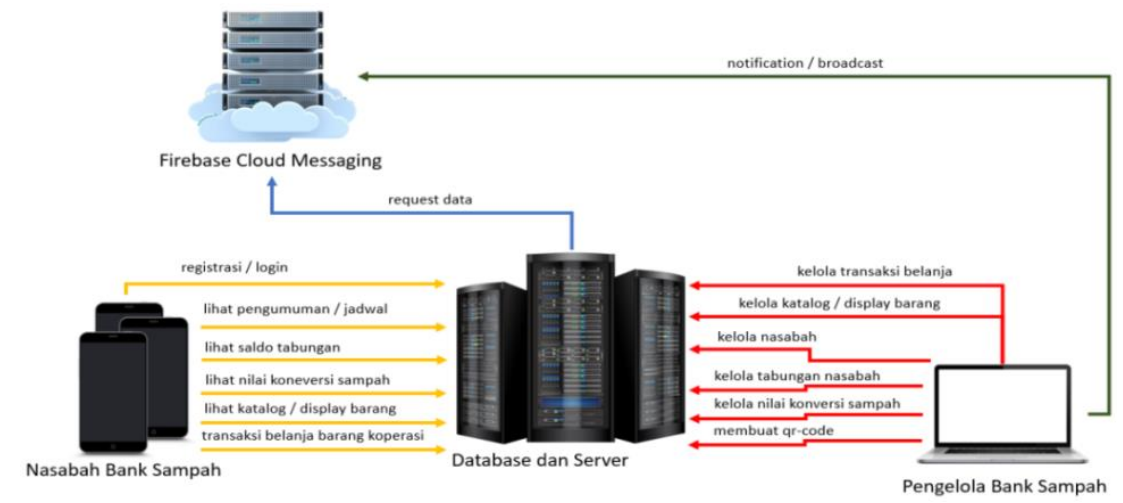

Figure 3. SAWOB M-Banking Application System Infrastructure SAWOB Android Application

\section{Benefits for the Community in the Tanjung Seto area}

The benefits that people get with the SAWOB (Sampah Wong Bae) Mobile Banking android application include: 1) Without having to come to the trash bank or ask the Karang Taruna administration, the waste bank committee, all information about the waste bank is simply acquired through the android application. 2) Make it easier for local people to save even if the amount is small without them having to go to the bank. 3) There are no more cases of losing waste savings books because all activities such as saving have been recorded in each customer's application. 4) Savings from the sale of waste do not need to be taken in cash but can be transferred to each customer's ATM and can be taken at any time. 5) Using the online buying and selling feature, cooperatives can conduct their purchasing and selling 
activities online. 6) People who are customers of waste banks can easily monitor and check the price of goods, increase or decrease in goods through the application. 7) This application is incredibly useful and efficient for admins or wastes bank administrators to coordinate online waste bank management, such as savings, without having to do it manually.

\section{CONCLUSION}

By establishing an android application SAWOB Mobile Banking, the community service program has met its production target by employing relevant technology as a medium to assist the waste bank process. The operational of waste bank in Bae is no longer done manually. This program has succeeded in developing an application that is efficient, effective, and practical for waste bank processing by using an application which integrates the Waste bank admin and customers (local people) for providing information related to the waste bank.. This success can be seen from the replacement of conventional waste bank processing to digital with the use of SAWOB android application (Sampah Wong Bae) Mobile Banking which is still ongoing and will be used sustainably. The administrators and customers say that the application is very effective and facilitates the workings of waste bank management. SAWOB Android-based application (Sampah Wong Bae) Mobile Banking can be followed up by providing sustainability assistance after the implementation of community service. This is intended so that the application continues to innovate based on the needs of waste management.

\section{REFERENCES}

Arifin, B., Ihsan, T., Tetra, O. N., Nofrita, N., Goembira, F., \& Adegustara, F. (2020). Pengelolaan bank sampah dalam mendukung go green concept di Desa Ulakan Tapakis Kabupaten Padang Pariaman. Jurnal Hilirisasi IPTEKS, 3(2), 169-178. https://doi.org/10.25077/jhi.v3i2.423

Asngad, A., \& Subiakto, Di. W. (2020). Potensi ekstrak biji alpukat sebagai hand sanitizer alami: Literatur review. Bioeksperimen: Jurnal Penelitian Biologi, 6(2), 106-115.

Aziz, A., \& Gumilang, S. F. S. (2018). Rancangan fitur aplikasi pengelolaan administrasi dan bisnis bank sampah di Indonesia. Konferensi Nasional Sistem Informasi (KNSI) 2018.

Deasy, A. (2020). Studi efektifitas bank sampah sebagai salah satu pendekatan dalam pengelolaan sampah tingkat Sekolah Menengah Atas (SMA) di Banjarmasin. JPG (Jurnal Pendidikan Geografi), 3(5), 22-37.

Dewanti, M., Purnomo, E. P., \& Salsabila, L. (2020). Analisa efektifitas bank sampah sebagai alternatif pengelolaan sampah dalam mencapai smart city di kabupaten Kulon Progo. Jurnal Ilmu Administrasi Publik, 5(1), 21-29.

Iftitah, L., \& Musta'in, M. M. (2018). Pemanfaatan bank sampah dalam peningkatan pendapatan masyarakat Kabupaten Jombang. Journal of Public Power, 2(1), 47-64.

Izzaty, R. E., Cholimah, N., \& Astuti, B. (2016). The implementation of an integrative model of adventure-based counseling and Adlerian play therapy value-based taught by parents to children to increase adjustment ability of preschool children. Asia Pacific Journal of Multidisciplinary Research, 4(4), 36-45. 
Khaira, M., Hasanah, U., \& Hayati, I. (2020). bank sampah dalam meningkatkan pendapatan ibu rumah tangga di Desa Sait Buttu Kec. Pematang Sidamanik. IHSAN: Jurnal Pengabdian Masyarakat, 2(2), 187-195.

Luluk, K. I. (2018). Penyuluhan 4R (Reduce, Reise, Recyle, Replace) dan kegunaakn bank sampah sebagai langkah menciptakan lingkungan yang bersih dan ekonomis di desa Mojowuku Kabupaten Gresik.

Muttaqien, K., Sugiarto, S., \& Sarifudin, S. (2019). Upaya meningkatkan kesadaran masyarakat terhadap kesehatan lingkungan melalui program bank sampah. Indonesian Journal Of Adult and Community Education, 1(1), 6-10.

Nasution, L., \& Ichsan, R. N. (2021). Sosialisasi peluang usaha bank sampah dalam peningkatan pendapatan masyarakat di masa Covid 19. PKM Maju UDA, 1(3), 107-112.

Santifa, M., Warjio, W., Harahap, D., \& Isnaini, I. (2019). Evaluasi program pemberdayaan masyarakat melalui bank sampah Mawar Sejadi di Kelurahan Sijambi Kecamatan Datuk Bandar Kota Tanjung Balai. Strukturasi: Jurnal Ilmiah Magister Administrasi Publik, 1(1), 89-98.

Santoso, P. (2020). Pengembangan manajemen bank sampah "Safa Marwa" Desa Wonokromo Bantul. Jurnal Sains Teknologi Dalam Pemberdayaan Masyarakat, 1(1), 27-32.

Wardany, K., Sari, R. P., \& Mariana, E. (2020). Sosialisasi pendirian "Bank sampah" bagi peningkatan pendapatan dan pemberdayaan perempuan di Margasari. Dinamisia: Jurnal Pengabdian Kepada Masyarakat, 4(2), 364-372.

Wartama, I. N. W., \& Nandari, Ni. P. S. (2020). Pemberdayaan masyarakat dalam pengelolaan sampah rumah tangga melalui bank sampah di desa Sidakarya Denpasar Selatan. Parta: Jurnal Pengabdian Kepada Masyarakat, 1(1), 44-48.

Copyright holder:
Farid Noor Romadlon, Dianing Ratna Wijayani, Wiwit Agus Triyanto (2022)

First publication right:

Devotion - Journal of Community Service

This article is licensed under:

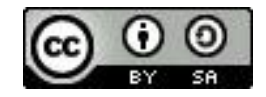

